\title{
A Cinnamomum cassia, a kínai orvoslás fontos gyógynövénye
}

\section{A fabéjszármazékok kontroll nélkiuli alkalmazásának veszélyei}

\author{
Blázovics Anna dr. - Héthelyi B. Éva
}

Semmelweis Egyetem, Gyógyszerésztudományi Kar, Farmakognóziai Intézet, Budapest

A fahéj Délkelet-Ázsiából származó füszer- és gyógynövény. A babérfélék családjába tartozó fahéjnak két fó faja és több száz fajtája ismert. A fó fajok a Cinnamomum cassia (vagy Cinnamomum aromaticum) és a Cinnamomum zeylanicum (vagy Cinnamomum verum) kéregdrogok gyógyító hatása évezredek óta ismert és kedvelt a délkelet-ázsiai népesség körében. Illóolajaik mind a Magyar (Ph. Hg. VIII.), mind az Európai (Ph. Eur. 9.0) Gyógyszerkönyvben szerepelnek.

A hagyományos kínai orvoslás gyógynövényei közé tartozó Cinnamomum aromaticum Nees (Lauraceae) fahéjfa örökzöld. A C. cassia fa őshonos Kínában, Vietnamban és Japánban. Dél-Amerikában, Mexikóban és Afrikában nagy területeken termesztik. A fa gyakran a 8-10 m-es magasságot is eléri. Kérgét 40-50 cm-es darabokban távolítják el, majd a kérget darabolják, porítják, előkészítik különböző készítmények előállítására. $A$ Cinnamomum zeylanicum Nees (ceyloni fahéj), vagy „valódi fahéj”, őshonos Srí Lankán (Ceylon), a környező szigetvilágban és Indiában. Termesztik például Iránban. Közepes méretú, örökzöld fa. Drogja értékesebb, mert illóolaj-tartalma magasabb, mint a $C$. cassia Blume fajoké. Paráját és elsődleges kérgét együtt hántják le, és a megtisztított kérget dolgozzák fel gyógyhatású termékekben [1]. A mindkét fajban megtalálható fó hatóanyag a fahéjaldehid [2]. A két fahéjfaj közötti legfontosabb különbség a kumarintartalomban van. A ceyloni fahéjban a kumarintartalom elhanyagolható, míg a C. cassia kumarinszintje jelentős. A kumarinok között véralvadásgátló és hepatotoxicus származékok ismertek [3]. Kínában évszázadok óta különböző betegségek kezelésére alkalmazzák a C. cassia fajokból készült Gui Zhi és Rou Gui készítményeket $[1,4]$.

\section{A hagyományos kínai orvoslás fahéjkészítményei}

\section{Gui Zhi}

A C. cassia Presl (Lauraceae), kínai nevén Gui Zhi, vagy Ramulus cinnamomi (Cinnamon twig), a fahéjfa száraz gallya. A herbát a jobb minőség érdekében általában tavasszal és nyáron gyüjtik, fóleg Guangdongban és Guangxiban. A betakarítás után eltávolítják a gallyról a leveleket, majd napon szárítják vagy frissen felszeletelik, és nyersen használják fel. A herba 1-2\% illóolajat tartalmaz, mely fahéjaldehidben és fahéjsavban gazdag. A fahéjaldehid megtalálható a kéregben, az ágakban (a vastagabb ágakban nagyobb mennyiségben) és a levelekben. Tartalmi anyagai többek között a kumarinok, a $\beta$-szitoszterol, a kolin, a protokatechusav, a vanillinsav és a sziringasav [5].

A Gui Zhi a fahéjaldehid-tartalma miatt gyenge diaphoreticus ágens, perifériás vasodilatatiós hatással. Közepes erősségű fájdalomcsillapító. Állatkísérletekben igazolták vérnyomáscsökkentő, valamint pozitív inotrop és chronotrop hatását. Antimikrobiális tulajdonságát szintén a fahéjaldehidnek tulajdonítják, mely hatást a nátrium-klorid fokozza. Nyugtató és görcsoldó, továbbá csökkenti az allergiás választ. Belsőleges használata nagy dózisban azonban kerülendő, mert például várandósoknál vetélést okozhat.

Általában izzasztóként használják a hideg, szeles időkben történő fertőzések leküzdésére, fejfájás, láz és hidegrázás ellen. Külsőleg arthralgiában alkalmazzák a vállak és a végtagok fájdalmának enyhítésére, izomgörcsök mérséklésére, de javasolják szabálytalan menstruációban, amenorrhoeás hasi fájdalomban és az epigastricus régióban jelentkező bizonytalan fájdalmakban. Teaforrázatait, vizes kivonatait ajánlják gyomorhurut, emésztési zavarok és étvágytalanság esetén [1].

A Gui Zhi toxicitása az $\mathrm{LD}_{50}$-értéket tekintve egérben intravénásan $132 \mathrm{mg} / \mathrm{kg}$, intraperitonealisan $610 \mathrm{mg} /$ $\mathrm{kg}$ és oralisan $2225 \mathrm{mg} / \mathrm{kg}$ [6].

\section{Rou Gui}

A Rou Gui fakérget Guangdong, Guangxi, Yunnan és Fujian tartományokban termesztett fákról nyerik. A $C$. cassia Blume (Lauraceae) Rou Gui cortex Cinnamomi (Cinnamomum bark) szárított kérge 1-2\% illóolajat tartalmaz, melynek fó komponense a fahéjaldehid. Ezen 
kívül tartalmaz nagyobb mennyiségben fahéjsavat és fenil-propil-acetátot. Számos diterpént, úgynevezett cinnkassziolt is izoláltak a kéregból. Ezek közül a fontosabbak a cinnkassziol A, B és $C_{1}$, valamint glükozidjaik, a $C_{2}$ és $C_{3}$, a cinnkassziol $D_{1}, D_{2}$ és ezek glükozidjai, $D_{3}$ és $\mathrm{D}_{4}$, valamint glükozidja a cinnkassziol $\mathrm{E}$, cinnzeylanol, cinnzeylanin, anhidrocinnzeylanol és anhidrocinnzeylanin, melyek a gyulladáscsökkentő hatást erősítik $[1,7]$. Aromás vegyületei többek között mérséklik a gastrointestinalis fekélyek okozta fájdalmakat. Kimutathatók még epikatechinszármazékok, fahéjaldehid-ciklikus-glicerol-, kassziozid- és cinnamozidszármazékok [8]. A kéreg vizes extraktuma kumarinokat, $\beta$-szitoszterolt, kolint, protokatechusavat, vanillinsavat és sziringasavat tartalmaz $[5,7]$.

A Rou Gui hasonló tulajdonságokkal rendelkezik, mint a Gui Zhi, ezért sok egyezés található terápiás alkalmazásában.

A Rou Gui és a Fu zi (radix Aconiti Lateralis preparata) keveréke szignifikáns hipotenzív hatást fejtett ki Conn-szindrómás patkányokban. A Rou Gui főzete jelentősen megnövelte a koszorúér-áramlást tengerimalacok izolált szívében, és részben antagonizálta a pituitrin miatt bekövetkező koszorúér-áramlás csökkentését. A fózet 6 napon keresztül napi 1,2 g/kg dózisban javította a pituitrin által kiváltott akut myocardialis ischaemiát nyulakban. Kutyák esetében az intravénásan adott $2 \mathrm{~g} / \mathrm{kg}$ fózet nem befolyásolta 1-2 perc alatt a vérnyomást, de jelentősen megnövelte a szívkoszorúérben és az agyban a véráramlást. A $100 \mathrm{mg} / \mathrm{kg}$ dózisban intraperitonealisan adott vizes extraktum megakadályozta a hideg atmoszféra $\left(3-5{ }^{\circ} \mathrm{C}\right)$ vagy vízbe merítés következtében jelentkező stresszfekély kialakulását patkányokban [6-8].

A Rou Guit javasolják impotenciában, frigiditásban, érzéstelenítő, fájdalomcsillapító hatása következtében nőgyógyászati (amenorrhoeában, dysmenorrhoeában) és hasi panaszok gyógyításában, de szédülés, szemgyulladás és torokfájás eseteiben is. Megkönnyíti a légzést.

A gyógynövény fơzetének intravénás $\mathrm{LD}_{50}$-értéke $18,48 \pm 1,80 \mathrm{~g} / \mathrm{kg}$ volt egerekben [6].

Napi 0,35 mg nátrium-cinnamáttal történő, 5 napig tartó subcutan kezelés 150-200\%-ban növelte a perifériás leukocytaszámot. A betegekben egyszeri, $36 \mathrm{~g}$ porított gyógynövény elfogyasztásakor nem várt mellékhatásként szédülés, homályos látás, növekvő szemnyomás, köhögés, oliguria, szomjúságérzet és pulzusnövekedés jelentkezett [6]. Készítményeinek túlzott alkalmazása súlyos, életveszélyes allergiás reakciókat válthat ki. Várandósságban ellenjavalt. Számos ország a C. cassia rendszeres használatát jelentős toxicitása miatt korlátozza [9].

\section{Mikrobiológiai, biokémiai és molekuláris biológiai kutatások}

A mikrobiológiai, biokémiai és molekuláris biológiai kutatások sora igazolja, hogy a hagyományos kínai orvoslás megfigyelései helytállóak.
A fahéjból elóállított illóolajok igazoltan baktericid és fungicid hatásúak. Gátolják a Gram-pozitív Staphylococcus aureus, a Gram-negatív Escherichia coli, Enterobacter aerogenes, Proteus vulgaris, Pseudomonas aeruginosa, Vibrio cholerae, Vibrio parahaemolyticus és Salmonella typhimurium törzseket. Gátolják továbbá a Candida specieseket, a dermatofita Microsporum gypseum, Trychophyton rubrum és Trychophyton mentagraphytes gombák növekedését [4].

Állatkísérletekben többek között igazolták, hogy a fahéjaldehid gátolja a $\mathrm{Na}^{+}-\mathrm{K}^{+}$-ATP-ázt a jejunumban [10], stimulálja a noradrenalin szekrécióját az ileum myentericus idegvégződéseiben [11]. A fahéjaldehid gátolja a NO-szintézist és szuppresszálja az indukálható NO-szintáz (iNOS) expresszióját RAW 246.7 makrofágkultúrában lipopoliszacharid-indukció alatt, valamint mind a fahéjaldehid, mind a 2'-metoxi, illetve 2'-hidroxi származékai gátolják a nukleárisfaktor-kappa-B (NF- $\kappa \mathrm{B})$ aktivációját $[12,13]$. Szövet- vagy sejttenyészetekben igazolták antimutagén és tumorellenes hatását is [14-17]. A fahéjsavval kapcsolatban végzett vizsgálatok szintén megerősítették a fahéj antiproliferatív és tumorellenes hatását $[18,19]$.

\section{A fahéj jelentősége 2-es típusú diabetes mellitusban}

A kínaiak a 2-es típusú diabetes kezelésében évszázadok óta alkalmazzák a fahéjkészítményeket.

A humángenom-vizsgálatoknak köszönhetően közel 60 gént azonosítottak, amelyek a cukorbetegség kialakulásában játszhatnak szerepet [20]. A dél- és délkelet-ázsiai népcsoportok esetében több olyan genetikai polimorfizmust is felfedeztek, amely hajlamosít a 2-es típusú cukorbetegségre [21].

Súlyosbító körülményként az életmódbeli, főleg étrendi tényezőket is figyelembe véve szoros összefüggést találtak a helytelen táplálkozás és a délkelet-ázsiai lakosság cukorbetegségének kialakulása között [22].

Korábbi vizsgálatok során azt találták, hogy a fahéjaldehid antidiabetikus ágens, és a fahéj hatásosan befolyásolja a szénhidrát- és a lipidanyagcserét, valamint mérsékli a hemoglobin-Alc (HbAlc)-szintet 2-es típusú diabetes mellitusban. E hatásokat a polifenolos vegyületek is támogatják $[23,24]$.

A fahéj biológiailag aktív komponensei képesek szabályozni a vércukorszintet inzulinutánzó tulajdonságuk révén, az inzulinreceptor-kináz aktivitásának, az inzulinreceptor autofoszforilációjának és a glikogén-szintáz aktivitásának fokozásával, aminek következtében nő a glükózfelvétel [25-29].

A humántanulmányokkal kapcsolatos legfrissebb öszszefoglaló munka, mely több cikk, könyvfejezet és preklinikai vizsgálat eredményeit dolgozza fel, azt állapította meg, hogy a leggyakrabban vizsgált fahéj a C. cassia volt, és csupán néhány éve tértek át a $C$. zeylanicum tanulmányozására, tekintettel arra, hogy a C. zeylanicum 
minimális mennyiségű kumarinszármazékot tartalmaz. A cikk szerzői a kifogásolható minőségú vizsgálatok és az eredmények heterogenitása (betegszám, dózis, kezelési idő) miatt úgy ítélik meg, hogy jelenleg nincs kellő bizonyíték a fahéj hatásosságára a 2-es típusú diabetes mellitus kezelésében [30]. A 2017-ben indított klinikai tanulmányok a C. zeylanicum kivonat antidiabetikus hatásának igazolására jelenlegi irodalomkutatásunk szerint még nem zárultak le (Trial registration: Sri Lanka Clinical Trials Registry [SLCTR], identifier: SLCTR/2017/010 [http://slctr.lk/trials/714]. Registered on 5 April 2017; study protocol version 3.1 21 March 2017) [31].

\section{A Magyarországon gyógyszertári és kereskedelmi fogalomban kapható fahéjkészítmények}

A Távol-Keletről hazánkba érkező gyógynövénykészítményekkel (porok, kivonatok, illóolajok) kapcsolatos ismeretek hiányosak, annak ellenére, hogy közülük számos szerepel a korábban említett Magyar Gyógyszerkönyvben és Európai Gyógyszerkönyvben is, illetve füszerként vagy étrend-kiegészítőként megvásárolhatók. Magyarországon jelenleg sem a Gui Zhi, sem a Rou Gui nem érhetó el legális úton, de beszerezhetók internetvásárláson keresztül. A Cinnamomi cassiae aetheroleum, a Cinnamomi zeylanici corticis aetheroleum és a Cinnamomi zeylanici folii aetheroleum viszont hazánkban gyógyszertári forgalomban kapható. A Ph. Hg. VIII. szerint a ceyloni fahéjfakéreg-olaj és a ceyloni fahéjfalevél-olaj jelentősen változatosabb illóolaj-összetételú, mint a kassziafahéj-olaj. A ceyloni fahéjfalevél-olaj fókomponense az eugenol (70-85\%), míg a ceyloni kéregolajé a transz-fahéjaldehid (55-75\%). A kassziafahéj-olaj fó komponense szintén a transz-fahéjaldehid (70-90\%), ugyanakkor eugenoltartalma kevesebb mint 0,5\%. E gyógyászati célokra szánt készítmények alkalmazási területe jelentôsen szúkebb, így például a fahéjillóolajok az aromaterápiában kerülnek alkalmazásra.

$\mathrm{Az}$ Evidence-Based Complementary and Alternative Medicine 2020-ban közölt cikkében a C. zeylanicum (Mashhad, Iran) kéreg fókkomponenseinek \%-os illóolajösszetétele gázkromatográfiás tömegspektrometriás (gas chromatography mass spectrometry, GC MS) vizsgálattal a következő volt: eukaliptol $(5,40 \%)$, linalool $(7,00 \%)$, fahéjaldehid $(71,50 \%)$, eugenol $(4,60 \%)$, $\beta$-kariofillén $(6,40 \%)$. Ezenkívül kimutattak még $\alpha$-pinén, benzaldehid, p-cimol, limonén, $\gamma$-terpinén, izoborneol, ecetsavasfahéjészter, $\alpha$-humulén, $\delta$-kadinén, transz-kalamén, kariofillén-oxid, benzil-benzoát összetevóket is [32].

A mérési eredményekből kitünik, hogy jelentős különbségek mutatkoznak a fahéjillóolajok összetételében, ami nemcsak a termesztési és feldolgozási körülményekben jelentkező különbségekből, hanem az analitikai módszerek különbözőségeiből is adódnak. Ugyanakkor az iráni fahéj illóolaja szintén hatásosan gátolta a Gram- pozitív Listeria innocua, Staphylococcus aureus és Bacillus cereus, valamint a Gram-negatív Escherichia coli, Pseudomonas aeruginosa és Salmonella typhi törzseket [32].

A hazánkban hivatalos kereskedelmi láncban kapható füszerek a C. zeylanicum fa kérgéből és leveléből származnak. Illóolaj-tartalmukban és egyéb összetevőikben saját kutatásaink alapján azonban jelentős különbségeket mutatnak (nem közölt adatok). A bioaktív vegyületekben mutatkozó eltérések különösen a bizonytalan eredetû étrend-kiegészítők esetében okozhatnak nem várt toxikus hatásokat, amelyeknél nem azonosított a fahéj faja és fajtája, illetve származási helye.

Mivel az étrend-kiegészítők piacán megjelenő fahéjtartalmú termékek klinikai tesztelése sajnálatos módon nem valósul meg, különösen az interneten keresztül történő étrendkiegészító-vásárlások során (webáruházak, online shopok, e-üzletek) a megtévesztő ajánlások miatt a készítmények egészségkárosító kockázattal járhatnak [33]. Éppen ezért étrend-kiegészítőként kizárólag megbízható forrásból származó termékeket szabad beszerezni; tekintettel arra, hogy az étrend-kiegészítőn semmiféle, egészségre vonatkozó adat nem szerepelhet, és a feliratok nem is sugallhatnak ilyen jellegú állitást, ki kell kérni megfelelő szakember véleményét az alkalmazás szükségszerüségéről.

Meg kell még említeni a különböző internetes oldalakon a fiatalok körében terjedő őrületet, a „Cinnamon challenge"-et, vagyis kanálnyi fahéjpor (nem egyértelmú, hogy milyen fahéj) víz nélküli lenyelését, ami allergiás, fulladásos, súlyos, életveszélyes reakciókat vált ki a korábban említett toxikus hatások miatt.

Mindezek ismeretében mind gyógyszerként, mind füszerként alkalmazva a fahéjtermékeket, azok mértéktartó fogyasztása szükséges.

\section{Irodalom}

[1] Zhu YP. Chinese materia medica. Chemistry, pharmacology and applications. CRC Press, Boca Raton FL, London, New York NY, Washigton DC, 1998.

[2] Harada M, Ozaki Y. Pharmacological studies on Chinese cinnamon. I. Central effect of cinnamaldehyde. Yakugaku Zasshi 1972; 92: 135-140.

[3] Lungarini S, Aureli F, Coni E. Coumarin and cinnamaldehyde in cinnamon marketed in Italy: a natural chemical hazard? Food Addit Contam. Part A. Chem Anal Control Expo Risk Assess 2008; 25: 1297-1305.

[4] Tang W, Eisenbrand G. Handbook of Chinese medicinal plants, chemistry, pharmacology, toxicology. Wiley-VCH, Weinheim, 2011.

[5] Yuan AX, Qin L, Jiang DG. Studies on the chemical constituents of Cinnamomum cassia. Chin Pharm Bull. 1981; 16: 631.

[6] Wang YS. Pharmacology and applications of chinese materia medica. People's Health Publisher, Beijing, 1983; pp. 442-446.

[7] Yuan AX, Tan L, Jiang DG. Studies on chemical constituents of Rou Gui (Cinnamomum cassia Presl). Bull Chin Mater Med. 1982; 7: 26-28.

[8] Tanaka S, Yoon YH, Fukui H, et al. Antiulcerogenic compounds isolated from Chinese cinnamon. Planta Med. 1989; 55: 245248 . 
[9] Ghosh P, Markin RS, Sorrell MF. Coumarin-induced hepatic necrosis. Am J Gastroenterol. 1997; 92: 348-349.

[10] Kreydiyyeh SI, Usta J, Copti R. Effect of cinnamom, clove and some of their constituents on the $\mathrm{Na}^{+}-\mathrm{K}^{+}$-ATPase activity and alanine absorption in the rat jejunum. Food Chem Toxicol. 2000; 38: 755-762.

[11] Cheng JT, Liu IM, Huang WC, et al. Stimulatory effect of transcinnamaldehyde on noradrenaline secretion in guinea-pig ileum myenteric nerve terminals. Life Sci. 2000; 66: 981-990.

[12] Lee HS, Kim BS, Kim MK. Suppression effect of Cinnamomun cassia bark-derived component on nitric oxide synthase. J Agric Food Chem. 2002; 50: 7700-7703.

[13] Lee HS, Lee SY, Son DJ, et al. Inhibitory effect of 2'-hydroxycinnamaldehyde on nitric oxide production through inhibition of NF- $\kappa$ B activation in RAW 264.7 cells. Biochem Pharmacol. 2005; 69: 791-799

[14] Sasaki YF, Ohta T, Imanishi H, et al. Suppressing effects of vanillin, cinnamaldehyde and anisaldehyde on chromosome abberations induced by X-rays in mice. Mutat Res. 1990; 243: 299302.

[15] Sasaki YF, Imanishi H, Watanabe M, et al. Suppressing effect of antimutagenic flavorings on chromosome aberrations induced by UV-light or X-rays in cultured Chinese hamster cells. Mutat Res. 1990; 229: 1-10.

[16] Sharma N, Trikha P, Athar M, et al. Inhibition of benzo[a]pyrene- and cyclophosphamide-induced mutagenicity by Cinnamomun cassia. Mutat Res. 2001; 480-481: 189-188.

[17] Liu L, Hudgins WR, Shack S, et al. Cinnamic acid: a natural product with potential use in cancer intervention. Int J Cancer $1995 ; 62: 345-350$

[18] Stammati A, Bonsi P, Zucco F, et al. Toxicity of selected plant volatiles in microbial and mammalian short-term assays. Food Chem Toxicol. 1999; 37: 813-823.

[19] Ekmekcioglu C, Feyertag J, Marktl W. Cinnamic acid inhibits proliferation and modulates brush border membrane enzyme activities in Caco-2 cells. Cancer Lett. 1998; 128: 137-144.

[20] Gujral UP, Pradeepa R, Weber MB, et al. Type 2 diabetes in South Asians: Similarities and differences with white Caucasian and other populations. Ann NY Acad Sci. 2013; 1281: 51-63.

[21] Anand SS, Meyre D, Pare G, et al. Genetic information and the prediction of incident type 2 diabetes in a high-risk multiethnic population: the EpiDREAM genetic study. Diabetes Care 2013; 36: $2836-2842$.

[22] Shah A, Kanaya AM. Diabetes and associated complications in the South Asian population. Curr Cardiol Rep. 2014; 16: 476.

[23] Crawford P. Effectiveness of cinnamon for lowering hemoglobin Alc in patients with type 2 diabetes: a randomized, controlled trial. J Am Board Fam Med. 2009; 22: 507-512.
[24] Blevins SM, Leyva MJ, Brown J, et al. Effect of cinnamon on glucose and lipid levels in non-insulin-dependent type 2 diabetes. Diabetes Care 2007; 30: 2236-2237.

[25] Ranasinghe P, Jayawardana R, Galappaththy P, et. al. Efficacy and safety of "true" cinnamon (Cinnamomum zeylanicum) as a pharmaceutical agent in diabetes: a systematic review and meta-analysis. Diabet Med. 2012; 29: 1480-1492.

[26] Cao H, Polansky MM, Anderson RA. Cinnamon extract and polyphenols affect the expression of tristetraprolin, insulin receptor, and glucose transporter 4 in mouse 3T3-Ll adipocytes. Arch Biochem Biophys. 2007; 459: 214-222.

[27] Imparl-Radosevich J, Deas S, Polansky MM, et al. Regulation of PTP-1 and insulin receptor kinase by fractions from cinnamon: implications for cinnamon regulation of insulin signalling. Horm Res. 1998; 50: 177-182.

[28] Jarvill-Taylor KJ, Anderson RA, Graves DJ. A hydroxychalcone derived from cinnamon functions as a mimetic for insulin in 3T3-Ll adipocytes. J Am Coll Nutr. 2001; 20: 327-336.

[29] Qin B, Nagasaki M, Ren M, et al. Cinnamon extract (traditional herb) potentiates in vivo insulin-regulated glucose utilization via enhancing insulin signaling in rats. Diabetes Res Clin Pract. 2003; 62: 139-148.

[30] Sierra-Puente D, Abadi-Alfie S, Arakanchi-Altaled K, et al. Cinammon (Cinnamomum spp.) and type 2 diabetes mellitus. Curr Top Nutraceut Res. 2020; 18: 247-255.

[31] Ranasinghe P, Galappaththy P, Constantine GR, et al. Cinnamomum zeylanicum (Ceylon cinnamon) as a potential pharmaceutical agent for type-2 diabetes mellitus: study protocol for a randomized controlled trial. Trials 2017; 18: 446.

[32] Behbahani BA, Falah F, Arab FL, et al. Chemical composition and antioxidant, antimicrobial, and antiproliferative activities of Cinnamomum zeylanicum bark essential oil. Evid Based Complement Alternat Med. 2020; 2020: 5190603. https://doi. org/10.1155/2020/5190603

[33] Lugasi A. Distribution of food supplements containing herbal active ingredients: legal environment, peer review. In: Blázovics A, Mézes M. (eds.) Natural active ingredients in modern medicine. [Növényi hatóanyagokat tartalmazó étrend-kiegészítők forgalmazása: jogi környezet, szakértői értékelés. In: Blázovics A, Mézes M. (szerk.) Természetes hatóanyagok a modern orvoslásban.] Szent István Egyetemi Kiadó Nonprofit Kft., Gödöllő, 2014; pp. 28-32. [Hungarian]

(Blázovics Anna dr., Budapest, Üllői út 26., 1085 e-mail: blazovics.anna@pharma.semmelweis-univ.hu)

A cikk a Creative Commons Attribution 4.0 International License (https://creativecommons.org/licenses/by/4.0/) feltételei szerint publikált Open Access közlemény, melynek szellemében a cikk bármilyen médiumban szabadon felhasználható, megosztható és újraközölhető, feltéve, hogy az eredeti szerző és a közlés helye, illetve a CC License linkje és az esetlegesen végrehajtott módosítások feltüntetésre kerülnek. (SID_1) 